\author{
KRYSTYNA ZARZECKA ${ }^{1}$, MAREK GUGAŁA ${ }^{1}$, IWONA MYSTKOWSKA ${ }^{2}$, \\ AliCJA BARANOWSKA ${ }^{2}$, ANNA SiKORSKA ${ }^{3}$, MAGDALENA ZARZECKA ${ }^{4}$ \\ ${ }^{1}$ Katedra Agrotechnologii \\ Uniwersytet Przyrodniczo-Humanistyczny w Siedlcach \\ Prusa 14, 08-110 Siedlce \\ ${ }^{2}$ Katedra Nauk o Środowisku \\ Państwowa Szkoła Wyższa im. Papieża Jana Pawła II w Białej Podlaskiej \\ Sidorska 95/97, 21-500 Biała Podlaska \\ ${ }^{3}$ Katedra Rolnictwa \\ Państwowa Wyższa Szkoła Zawodowa w Ciechanowie \\ Narutowicza 9, 06-400 Ciechanów \\ ${ }^{4}$ Mazowiecki Szpital Wojewódzki w Siedlcach \\ Poniatowskiego 26, 08-110 Siedlce \\ E-mail:kzarzecka@uph.edu.pl \\ gugala@uph.edu.pl
}

\title{
ODŻYWCZE I PROZDROWOTNE WŁAŚCIWOŚCI ZIARNA OWSA I PRZETWORÓW OWSIANYCH*
}

\section{POCHODZENIE, UPRAWA I HODOWLA}

Owies siewny, zwany też zwyczajnym (Avena sativa L.), należy do rodziny Trawy (Poaceae). Jest młodszą roślina uprawna, podobnie jak żyto, gdyż do Europy dotarł z Azji jako chwast towarzyszacy uprawom jęczmienia i pszenicy. Najstarsze ślady owsa pochodza ze Szwajcarii $z$ epoki brazu i dotycza owsa szorstkiego (A. strigosa). Następnie pojawiły się owies głuchy (A. fatua L.) i owies siewny ( $A$. sativa L.). W średniowieczu owsianka stanowiła podstawę wyżywienia ludności Europy, a dla angielskich górników był to idealny posiłek dajacy siłę do ciężkiej pracy. Zainteresowanie tym zbożem wynikało $z$ faktu, że charakteryzowało się ono dużymi zdolnościami przystosowawczymi do niekorzystnych warunków siedliskowych. Uprawę owsa na terenie Polski rozpoczęto w VIIIIX w., a hodowlę odmian datuje się na koniec XIX w. (BUDZYŃSKI i SZEMPLIŃSKI 1999). $\mathrm{W}$ połowie $\mathrm{XX} \mathrm{w}$. owies $\mathrm{w}$ naszym kraju uprawiano na powierzchni ponad dwóch milionów hektarów, co było zwiąane $z$ wykorzystaniem ziarna jako paszy dla koni, a w 2015 r. zajmowal areał 460 tys. ha. Śred- nie plony nie należa do wysokich, w 2015 r. wynosiły 2,65 t $z 1$ ha, podczas gdy w doświadczeniach wahaja się $\mathrm{w}$ granicach 5-7 t $Z$ ha. Aktualnie uprawia się dwa gatunki owsa: owies zwyczajny (A. sativa L.) i owies nagoziarnisty zwany też nagim (A. nuda L.) (LISTA 2015, WYNIKI 2016).

Hodowla każdego gatunku rośliny wiąże się $z$ jego znaczeniem i wykorzystaniem. Do niedawna owies był gatunkiem typowo pastewnym, na paszę przeznaczano ponad $80 \%$ ziarna, a na konsumpcje tylko 2-3\% (BUDZYŃSKI i SZEMPLIŃSKI 1999). W ostatnich latach zwiększyło się wykorzystanie konsumpcyjne ziarna do około $5 \%$, natomiast $\mathrm{w}$ krajach Unii Europejskiej na cele spożywcze przeznacza się ponad 9\% (KAWKA i ACHREMOWICZ 2014). Prowadzone prace hodowlane w coraz większym zakresie uwzględniaja potrzeby oraz wymagania żywieniowe i zdrowotne konsumenta. Maja one na celu zmniejszenie udziału łuski, który w starszych odmianach wynosił 25-30\%. W wyniku prac hodowlanych już w 2002 r. zarejestrowano i wprowadzono do uprawy pierwsza odmianę nagoziarnista "Polar". Ziarniaki nieoplewione, w porównaniu do oplewionych,

*Artykuł opracowano w ramach tematu badawczego $\mathrm{nr}$ 363/13/S finansowanego $z$ dotacji na naukę przyznanej przez Ministerstwo Nauki i Szkolnictwa Wyższego.

Słowa kluczowe: ziarniak owsa, skład chemiczny, wartość odżywcza, walory zdrowotne 
mają mała zawartość włókna, a dużą białka i tłuszczu, co zwiększa ich atrakcyjność jako surowca dla przemysłu spożywczego, kosmetycznego i farmaceutycznego. Ujemna strona odmian nieoplewionych jest mniejsza plenność, w porównaniu do oplewionych (PISULEWSKA 2005, MYszKa i Boros 2013, LISTA 2015).

W 2015 r. w krajowym rejestrze znajdowało się 30 odmian, w tym 25 owsa zwyczajnego (oplewionego) i 5 odmian owsa nagiego. Większość odmian owsa zwyczajnego (23) przydatnych jest do uprawy na nizinach, a dwie na wyżej położonych terenach podgórskich i górskich (sa to tzw. odmiany górskie). Natomiast odmiany owsa nagoziarnistego przeznaczone sa na tereny nizinne. Ważnym jest, że nowo rejestrowane odmiany odznaczaja się dobra plennościa i odpornościa na choroby oraz wysoką wartością odżywczą (LISTA 2015).

\section{OPIS BOTANICZNY OWSA ZWYCZAJNEGO}

Owies jest roślina jednoroczna, występujaca $\mathrm{w}$ formie jarej i ozimej. W naszym kraju uprawia się tylko formę jara, gdyż odmiany ozime odznaczaja się mała mrozoodpornością. Owies ma system korzeniowy wiazkowy. Jest on dobrze rozwinięty, główna masa korzeni mieści się w warstwie ornej, natomiast pojedyncze korzenie moga sięgać do $2 \mathrm{~m}$ w głąb gleby. Korzenie owsa bardzo dobrze wykorzystuja składniki pokarmowe ze zwiazków trudno dostępnych, stąd roślina ta lepiej plonuje na słabszych glebach niż inne zboża. Łodyga, nazywana źdźbłem, wyrasta do $50-170 \mathrm{~cm}$ wysokości. Liście sa szerokie, kształtu lancetowatego, a kwiatostanem owsa jest wiecha. Na końcu osi głównej wiechy i na odgałęzieniach znajduja sie kłoski 1-3 kwiatowe, $z$ których tworza się 1-3 ziarniaki. Każdy ziarniak zamykaja dwie plewki zwane łuskami. Stąd mówi się, że owies jest nieobłuszczony, a u ziarniaka owsa nagiego plewek brak (BUDZYŃSKI i SZEMPLIŃSKI 1999).

Owies ma małe wymagania glebowe i cieplne, ale spośród wszystkich gatunków roślin zbożowych wyróżnia się największymi wymaganiami wodnymi. Dzięki niewielkim wymaganiom termicznym, owies uprawia się nawet wysoko w górach, czyli tam, gdzie zawodzą inne rośliny ze względu na niskie temperatury i krótki okres wegetacji. Zaleta owsa jest też duża tolerancja na niskie $\mathrm{pH}$ gleby, stąd może być $z$ powodzeniem uprawiany na glebach kwaśnych i obojętnych, pod warunkiem, że sa one wilgotne $\dot{i}$ zasobne $\mathrm{w}$ niezbędne składniki. Innym walorem tej rośliny jest to, że jest dobrym przedplonem dla wszystkich zbóż i dobrze toleruje uprawe po zbożach (PISUlEwSKA 2005, LiSTA 2015).

\section{SKŁAD CHEMICZNY A WALORY ŻYWIENIOWE I ZDROWOTNE OWSA}

Ziarno owsa jest głównie przeznaczane na paszę, ale $\mathrm{w}$ ostatnich latach coraz częściej nabiera znaczenia jako składnik zdrowej, dobrze zbilansowanej diety ludzi, a dyktuja to potrzeby oraz wymagania zdrowotne i żywieniowe współczesnego konsumenta, w tym szczególnie dzieci i osób starszych (HAVRLENTOVÁ i współaut. 2011, KAWKA i ACHREMOWICZ 2014).

Ziarno A. sativa odznacza się wyjatkowa kombinacja składników odżywczych, która decyduje o jego wartości żywieniowej, dietetycznej, leczniczej oraz szerokim wykorzystywaniu $\mathrm{w}$ przetwórstwie. Owies jest jednym $\mathrm{z}$ cenniejszych zbóż, a jego ziarno, ze względu na skład chemiczny, różni się od podstawowych gatunków przede wszystkim mniejszą zawartościa węglowodanów (owies 53\%, pszenica 65\%, żyto 69\%, jęczmień 64\%) oraz większa zawartościa tłuszczu (owies 4-9\%, pszenica $2 \%$, żyto $1,7 \%$, jęczmień 2\%) (PISULEWSKA 2005, KORZENIOWSKA-GINTER i KAMIŃSKA 2014). Ponadto, ze wszystkich zbóż, ziarno owsa jest nie tylko najbogatsze w białko, ale tworzy je najlepszy zestaw aminokwasów, które determinują jego wartość odżywcza. Spośród dwudziestu aminokwasów człowiek jest w stanie syntetyzować tylko dziewięć aminokwasów endogennych, pozostałe aminokwasy egzogenne należy dostarczyć z pożywieniem. W ziarnie owsa występuja aminokwasy egzogenne takie jak: treonina, metionina, lizyna, fenyloalanina, tyrozyna, walina, leucyna. W białku owsa aminokwasy egzogenne stanowia 41\%, natomiast w białku pszenicy i żyta tylko 33\% (CZUBASZEK 2003, GiBIŃSKI i współaut. 2005, VILMANE i współaut. 2015). GiBIŃsKI i współaut. (2005), na podstawie danych literaturowych stwierdzili, że spożycie $100 \mathrm{~g}$ płatków owsianych pokrywa dzienne zapotrzebowanie człowieka na siedem aminokwasów egzogennych. Pod względem żywieniowym najcenniejsza jest frakcja globuliny, która w białku owsa stanowi $50-80 \%$, natomiast $w$ pozostałych zbożach $2-12 \%$. Globuliny sa odpowiedzialne za mechanizmy odpornościowe, także wiąża tłuszcze i glukozę (KoRZENIOWSKA-GINTER i KAMIŃSKA 2014). Ziarno zawiera też białka typu awenin (prolaminy) i glutelin w ilości około 20\%, których frakcje w pozostałych zbożach stanowia 75-94\% (KAWKA i ACHREMOWICZ 2014). Prolaminy (awenina) zawarte $\mathrm{w}$ ziarnie $\mathrm{i}$ przetworach moga być brane pod uwage $\mathrm{w}$ diecie stosowanej przy zespole chorobowym, zwanym choro- 
Tabela 1. Skład chemiczny ziarna owsa i płatków owsianych w \% (GIBIŃski i współaut. 2005, PISULEWSKA 2005, RZEDZICKI 2006, JURGA 2011, LISTA 2015).

\begin{tabular}{|c|c|c|c|c|c|}
\hline Produkt & Białko ogólne & Tłuszcz surowy & Błonnik pokarmowy & Skrobia & Popiół surowy \\
\hline $\begin{array}{l}\text { Odmiany oplewione owsa } \\
\text { (nieobłuszczone) }\end{array}$ & $11,4-15,8$ & $3,8-5,0 \quad(9,0)$ & $27,2-32,7$ & $40,5-44,9$ & $1,4-2,7$ \\
\hline $\begin{array}{l}\text { Odmiany nagie } \\
\text { (obłuszczone) }\end{array}$ & $13,5-16,5$ & $6,3-8,6$ & $12,0-15,0$ & $56,0-60,8$ & $1,7-2,0$ \\
\hline Płatki owsiane & $12,5-15,2$ & $6,3-10,1$ & $17,8-23,0$ & $40,0-42,0$ & $1,6-1,9$ \\
\hline
\end{tabular}

bą trzewna lub celiakią. Natomiast prolaminy innych zbóż: gliadyna pszenicy, sekalina żyta, hordeina jęczmienia, wywołuja objawy celiakii (GIBIŃSKI i współaut. 2005).

Wartość odżywcza białka pokarmowego owsa wykorzystywanego na cele budulcowe oceniana wskaźnikami biologicznymi plasuje owies na pierwszym miejscu, a w dalszej kolejności są: żyto, jęczmień, pszenica (BIEL i współaut. 2010, JURGA 2011, KAWKA i ACHREMOWICZ 2014). Zawartość białka, a także innych składników, w ziarnie, płatkach owsianych i innych przetworach zależą od wielu czynników, m.in.: od odmiany owsa (oplewione i nieoplewione), zabiegów agrotechnicznych, warunków klimatyczno-glebowych, stąd zawartości sa zróżnicowane, co przedstawiono w Tabeli 1.

W porównaniu do innych zbóż, ziarno owsa zawiera najwięcej tłuszczu, do 5\% w ziarnie nieobłuszczonym, ponad $8 \%$ w odmianach nagich (3-4 razy więcej niż w innych zbożach), w płatkach owsianych nawet $10 \%$, a w otrębach około 11\%. Również w niektórych odmianach oplewionych zawartość tłuszczu jest duża, dochodzi do 9\%, np. u odmian Komfort, Paskal (LisTA 2015). Tłuszcz ten, ze względu na skład chemiczny, jest bardzo cenny, bo zawiera niezbędne nienasycone kwasy tłuszczowe (NNKT), których organizm człowieka nie potrafi wytwarzać. W oleju owsianym dominują: kwas linolowy (24-53\%), oleinowy (35\%) i palmitynowy (20\%), stanowiąc łącznie około 80\% (ZHOU i współaut. 1999, KAWKA i ACHREMOWICZ 2014). Spożycie 100 g płatków pokrywa w 30\% dzienne zapotrzebowanie człowieka na kwas linolowy (GÁsIOROWSKI 2003). Kwasy NNKT biora udział w przemianach biochemicznych i w regulacji czynności fizjologicznych, ponadto zapobiegaja powstawaniu zakrzepów, odgrywają dużą rolę w profilaktyce i w leczeniu miażdżycy, poprawiaja pracę serca i krążnie krwi. Wyniki badań wskazuja, że kwas oleinowy, który także wysteppuje we frakcji tłuszczowej owsa, chroni przed nowotworami (GAsIOROWSKI 2003, LANGE 2010, PIĄTKOWSKA i współaut. 2010a).
Weglowodany, podobnie jak w pozostałych zbożach, stanowią główną część suchej masy ziarna owsa. Owies charakteryzuje się większą zawartością białka i tłuszczu, stąd w porównaniu do innych zbóż, gromadzi mniej węglowodanów, wśród których dominuje skrobia. Owies zawiera jej około 10\% mniej niż pozostałe zboża, lecz jest lepiej przyswajalna. Znaczenie skrobi wynika $Z$ jej podatności na hydrolizę enzymatyczna i możliwość wchłaniania produktów rozkładu powstałych w jelicie cienkim. Częściowo strawiona skrobia ma podobny wpływ jak włókno pokarmowe - skraca czas pasażu treści pokarmowej oraz modyfikuje aktywność enzymów trawiennych. Oprócz skrobi, w mniejszych ilościach występuja cukry rozpuszczalne i dekstryny. Do węglowodanów należy również włókno pokarmowe, które stanowi znaczną ich część, a określane jest najczęściej jako polisacharydy nieskrobiowe (GIBIŃsKI i współaut. 2005, PIĄTKOWSKA i współaut. 2010a, BRUNAVA i współaut. 2014).

Cennym składnikiem owsa jest błonnik pokarmowy, a owies jest rekordzista wśród zbóż pod względem jego zawartości. $Z$ danych literaturowych wynika, iż ilość błonnika w ziarnie jest zróżnicowana, a odmiany nieobłuszczone zawieraja go więcej, w granicach 27,2-32,7\%, niż obłuszczone (12-15\%), a płatki owsiane 17,8-23,0\% (Tabela 1) (GĄSIOROWSKI 2003, GIBIŃSKI i współaut. 2005, RZEDZICKI 2006, JURGA 2011). W błonniku wyróżnia się frakcję rozpuszczalna, która stanowi 40-60\%, i nierozpuszczalna (LuTOWSKA i współaut. 2008). Błonnik rozpuszczalny, $z$ dietetycznego punktu widzenia, jest bardziej pożądany, gdyż korzystnie wpływa na układ pokarmowy, reguluje poziom glukozy we krwi, wpływa na stężenie cholesterolu (KAWKA i ACHREMOWICZ 2014).

Z kolei frakcja nierozpuszczalna błonnika zwiększa uczucie sytości i zmniejsza spożycie pokarmów. Ponadto, wiąże kwasy żółciowe i hamuje ich przekształcanie się w związki o charakterze kancerogennym. Najwięcej błonnika pokarmowego gromadza 
Tabela 2. Zawartość makroelementów w ziarnie owsa oplewionego i nagiego w \% suchej masy (SZUMIŁO i RACHOŃ 2006, BARCZAK i NOWAK 2013, WiTKOWICZ 2016).

\begin{tabular}{cccccc}
\hline Ziarno owsa & Fosfor & Potas & Magnez & Wapń & Sód \\
\hline $\begin{array}{c}\text { Odmiany oplewione owsa } \\
\text { (nieobłuszczone) } \\
\begin{array}{c}\text { Odmiany nagie } \\
\text { (obłuszczone) }\end{array}\end{array}$ & $0,33-0,40$ & $0,53-0,60$ & $0,12-0,14$ & $0,11-0,16$ & $0,07-0,09$ \\
\hline
\end{tabular}

otręby owsiane, następnie płatki, a najmniej ziarno obłuszczone (GIBIŃSKI i współaut. 2005). Przetwory owsiane wyróżnia też niska wartość wskaźnika glikenicznego (GI), stąd zalecane jest profilaktyczne właczanie ich do diety u osób zdrowych, a lecznicze u diabetyków (BARTNIKOWSKA 2003).

Unikatowe właściwości prozdrowotne przypisuje się beta-glukanom, które sa głównym składnikiem frakcji rozpuszczalnej błonnika owsa. Ziarno owsa i jego przetwory, dzięki obecności beta-glukanów, stosowane sa do wytwarzania produktów nowej generacji, m.in. w przemyśle spożywczym, np. jako zamienniki zagęstników i stabilizatorów do lodów, sosów (zamiast żelatyny) czy dodatki funkcjonalne w produkcji żywności. Beta-glukany maja zdolność tworzenia w przewodzie pokarmowym lepkich żeli, w wyniku czego zwiększa się objętość pożywienia, a tym samym zaspokojenie uczucia łaknienia i spowalnia się pasaż treści pokarmowej. Zwiększenie lepkości treści jelita ogranicza wchłanianie tłuszczu i cholesterolu i wzmaga wydalanie kwasów żółciowych $z$ organizmu. Jednocześnie wzrost masy treści jelita grubego sprzyja rozproszeniu toksycznych metabolitów i związów kancerogennych, a masa kałowa nie tworzy zastoin i zaparć. Następuje hamowanie namnażania bakterii gnilnych powodujacych ogniska zapalne będace źródłem owrzodzeń, a nawet ognisk nowotworowych (GAMBUŚ i współaut. 2006, GIBIŃSKI i SIKORA 2009). Ponadto, zżelowane beta-glukany opóźniaja hydrolizę skrobi i wchłanianie cukrów, co przyczynia się do zmniejszenia stężenia glukozy we krwi po posiłku. Żele wiążą składniki odżywcze i zmniejszają ich wchłanianie przez komórki nabłonka. Jednocześnie dostęp enzymów trawiennych do weglowodanów jest utrudniony. $Z$ tego względu beta-glukany owsiane sprawiaja, że glikemia ma znacznie łagodniejszy przebieg, a także obniżają ryzyko chorób cywilizacyjnych (GIBIŃSKI i współaut. 2005, MYSZKA i BOROS 2013, KAWKA i ACHREMOWICZ 2014). JURCZYŃSKA i współaut. (2012) donosza, że beta-glukany zwiększaja odporność organizmu na infekcje wirusowe, bakteryjne i grzybicze, oraz ograniczają niszczace działanie komórek nowotworowych.
Spośród podstawowych zbóż, ziarno owsa jest najbogatsze w składniki mineralne. W ziarnie i jego produktach w największych ilościach występują zwiazki: wapnia, magnezu, fosforu, potasu, żelaza, miedzi, manganu, o czym decyduja przede wszystkim: odmiana, warunki klimatyczne podczas wegetacji i zabiegi agrotechniczne (SzUMiŁo i RACHOŃ 2006, PIĄTKOWSKA i współaut. 2010a, WiTKOWICZ 2016). Forma nagoziarnista owsa zawiera więcej fosforu, magnezu i sodu, natomiast mniej potasu i wapnia niż odmiany oplewione (Tabela 2).

Owies i jego przetwory zawieraja znaczne ilości witamin $z$ grupy $B$, zwłaszcza $B_{1}$ oraz rozpuszczalne w tłuszczach: A, D, E i K (MYszKA i Boros 2013). Ziarno owsa stanowi też źródło związków bioaktywnych o właściwościach przeciwutleniajacych, a do najważniejszych należą: polifenole, kwas fitynowy, awentramidy (MYSZKA i BOROS 2013). Najbardziej liczne sa związki fenolowe, które inaktywuja wolne rodniki, działaja bakteriostatycznie, reguluja pracę serca zmniejszając nadciśnienie i wahania ciśnienia krwi. Kwas fitynowy obecny w ziarnie owsa wpływa na zmniejszenie ryzyka wystapienia miażdżycy i cukrzycy. Awentramidy, jako specyficzne polifenole, wyróżniają się właściwościami przeciwzapalnymi, antyasmatycznymi, przeciwmiażdżycowymi (BARTNIKOWSKA 2003, PIĄTKOWSKA i współaut. 2010b, KAWKA i ACHREMOWICZ 2014). Wielu autorów stwierdziło korzystny wpływ dodatku płatków owsianych, maki czy innych przetworów owsianych na wartość odżywczą i poprawę cech sensorycznych pieczywa pszennego (RzEDZICKI 2006, SoBCZYK i współaut. 2010).

\section{INNE MOŻLIWOŚCI WYKORZYSTANIA OWSA}

Ziarno owsa i jego przetwory sa stosowane do wytwarzania produktów kosmetycznych, m.in. do szamponów, płynów kąpielowych, odżywek, kremów, smietanek kosmetycznych, mydła toaletowego. Kosmetyki owsiane $Z$ substancjami śluzowymi tworza na skórze cieniutki i niewyczuwalny filtr ochronny, który osłania ja przed niekorzystnym oddziaływaniem czynników zewnętrz- 
nych (bariera naskórkowa). Działają nawilżająco i wygładzająco, posiadają właściwości zbliżone do kwasu hialuronowego odpowiedzialnego za elastyczność skóry, a więc opóźniaja efekty jej starzenia (KAWKA i ACHREMOWICZ 2014). Produkty owsiane sa wykorzystywane w farmacji, m.in. jako składniki leków, suplementy diety. Beta-glukany owsiane przyspieszaja gojenie się ran, szczególnie pooparzeniowych, redukuja ból i powoduja zabliźnianie ran $z$ defektami kosmetycznymi. Opatrunek żelowy BGC łączy beta-glukany $z$ kolagenem. Beta-glukany wystepuja w opatrunku jako złożony polisacharyd i znany stymulant makrofagów, natomiast kolagen w roli naturalnego składnika skóry.

Wodne wyciagi $z$ ziela owsa działaja wykrztuśnie oraz przeciwbólowo w schorzeniach reumatycznych, kamicy moczowej i chorobach nerek. Ponadto, stanowia dobry środek mineralizujacy, bogaty $\mathrm{w}$ rozpuszczalną w wodzie krzemionke, wpływająca dodatnio na przemianę materii, stan naczyń krwionośnych, narządów wewnętrznych, kości, skóry, włosów i paznokci (LAJS 2013). WITKOwICZ i współaut. (2015) również wykazali, że ziele owsa różnych genotypów jest cennym źródłem składników mineralnych, białka oraz polifenoli.

Owies i jego przetwory nie sa dotychczas należycie doceniane i wykorzystywane. Natomiast skład chemiczny, walory odżywcze i prozdrowotne, zwłaszcza w dobie stosowania coraz bardziej nowoczesnych technologii, wskazują na duże możliwości wykorzystania owsa w przetwórstwie, dietetyce, lecznictwie $i$ innych dziedzinach.

\section{Streszczenie}

W pracy przedstawiono krótka historię uprawy owsa, charakterystykę botaniczna, skład chemiczny ziarna, wartość odżywczą i prozdrowotna oraz wielostronne wykorzystanie. Owies i jego produkty sa cennym źródłem wielu bioaktywnych składników odżywczych i substancji, takich jak: białka, lipidy, składniki mineralne, witaminy, błonnik pokarmowy, beta-glukany, polifenole. Owies jest zbożem o prozdrowotnym działaniu na organizm człowieka. Zdaniem żywieniowców i lekarzy, produkty owsiane moga stanowić cenne uzupełnienie diety, zwłaszcza u osób $z$ chorobami, takimi jak: zaburzenia czynności przewodu pokarmowego, miażdżyca, nadciśnienie, nadwaga czy obniżona sprawność psychofizyczna.

\section{LITERATURA}

BARCZAK B., NOWAK K., 2013. Content of macroelements and their ionic ratios in oat grain depending on the sulphur form and dose. J. Central Europ. Agric. 14, 114-123.

BARTNIKOWSKA E,. 2003. Przetwory $z$ ziarna owsa jako źródło ważnych substancji prozdrowotnych $w$ żywieniu człowieka. Biuletyn IHAR 229, 235-245.

BIEL W., SzOŁKOWSKA A., BoBKo K., JASKOWSKA I., 2010. Skład chemiczny i jakość białka bra- zowo- $i$ żółtoplewkowego. Folia Pomer. Univ. Technol. Stetin. Agric. Aliment. Pisc. Zootech. 278, 39-48.

Brunava L., Alsina I., Zute S., Sterna V., Vicupe Z., 2014. Some chemical, yield and quality properties of domestic oat cultivars. $9^{\text {th }}$ Baltic Conference on Food science and Technology "Food for Consumer Well-being" FOODBALT 2014. Conference proceedings, 72-76.

BUDZYŃSKI W., SZEMPLIŃSKI W., 1999. Owies. [W:] Szczegółowa uprawa roślin. Tom 1. JASINSSA Z., KOTECKI A. (red.). Wyd. AWA, Wrocław, 235-262.

CZUBASZEK A., 2003. Wybrane cechy fizyczne $i$ skład chemiczny ziarna kilku odmian owsa. Biuletyn IHAR 229, 307-315.

Gambuś H., GiBiński M., GamBuś F., 2006. Możliwość zastapienia tłuszczu $w$ herbatnikach maltodekstryna owsiana. Biul. IHAR 239, 319328.

GĄSIOROWSKI H., 2003. Wartość fizjologiczno-żywieniowa owsa. Przegląd Zbożowo-Młynarski 3, 26-28.

GIBIŃSKI M., SIKORA M., 2009. Spożywcze $i$ niespożywcze zastosowanie $\beta$-glukanów. Wyd. Uniwersytetu Przyrodniczego w Krakowie.

GIBIŃSKI M, Gumul D., KorUS J., 2005. Prozdrowotne właściwości owsa i produktów owsianych. Żywność Nauka Technologia Jakość 4 (Supl.), 49-60.

Havrlentová M., Petruláková Z., Burgárová A., Gago F., HLinková A., ŠTuRdík E., 2011. Cereal $\beta$-glucans and their significance for the preparation of functional foods - a review. Czech J. Food Sci. 29, 1-14.

JURCZYŃSKA E., SACZKO J., KULBACKA J., KAWA-RYGIELSKA J., BŁAŻEWICZ J., 2012. Beta-glukan, jako naturalny antykarcynogen. Pol. Merk. Lek. 33, 217-220.

JURGA R., 2011. Skład chemiczny, wartość żywieniowa $i$ możliwości wykorzystania owsa $i$ jego przetworów. Przegląd Zbożowo-Młynarski 5, 28-31.

KAWKA A., ACHREMOWICZ B., 2014. Owies - roślina XXI wieku. Wykorzystanie żywieniowe $i$ przemysłowe. Nauka Przyroda Technologie 8, 32-41.

KORZENIOWSKA-GINTER R., KAMIŃSKA A., 2014. Wiedza konsumentów na temat prozdrowotnych właściwości owsa oraz wykorzystanie przetworów owsianych $w$ żywieniu. Zesz. Nauk. Akademii Morskiej w Gdyni 86, 125-132.

LAJS I., 2013. Fitochemiczne badania porównawcze wyciagów ze swieżych $i$ wysuszonych surowców roślinnych. Praca doktorska, Uniwersytet Medyczny w Poznaniu, 1-161.

LANGE E., 2010. Produkty owsiane jako żywność funkcjonalna. Żywność Nauka Technologia Jakość 3, 7-24.

LISTA (Lista opisowa odmian roślin rolniczych. Zbożowe), 2015. Wyd. Centralnego Ośrodka Badania Odmian Roślin Uprawnych, Słupia Wielka, 1-188.

LUTOWSKA M., TYRANOWSKA M., KIRYLUK J., MAKOWSKA A., 2008. Cechy ziarna owsa jako surowca do produkcji otrab owsianych. Przeglacd Zbożowo-Młynarski (Biuletyn) 8, 19-21.

MyszKA K., BoROS D., 2013. Poszukiwanie genotypów owsa o poprawionej wartości odżywczej oraz wysokich właściwościach bioaktywnych. Biul. IHAR 268, 101-112.

PiąTKOWSKA E., WitKOWICZ R., PISUlEWskA E., 2010a. Podstawowy skład chemiczny wybranych odmian owsa siewnego. Żywność Nauka Technologia Jakość 3, 88-99. 
PiAtKowska E., WiTKOWICZ R., PISUlEWSKA E., 2010b. Właściwości antyoksydacyjne wybranych odmian owsa siewnego. Żywność Nauka Technologia Jakość 3, 100-107.

PISUlEWSKA E., 2005. Owies. [W:] Rynki i technologie produkcji roślin uprawnych. CHOTKOWSKI J. (red.). Wyd. Wieśs Jutra, Warszawa, 182196.

RZEDZICKI Z., 2006. Charakterystyka składu che micznego wybranych przetworów owsianych. Biul. IHAR, 239, 269-280.

SOBCZYK M., HABER T., WITKOWSKA K., 2010. Wpływ dodatku płatków owsianych na jakość ciasta i pieczywa pszennego. Acta Agrophys. $16,423-433$.

SzUMilo G., RACHOŃ L., 2006. Porównanie plonowania $i$ jakości owsa nagoziarnistego $i$ ople wionego $w$ warunkach zróżnicowanej ochrony chemicznej. Biul. IHAR 239, 85-92.

Vilmane L., ZuTE S., Straumîte E., Galoburda R., 2015. Protein, amino acid and gluten con- tent in oat (Avena sativa L.) grown in Latvia. Proc. Lat. Acad. Sci. B, 69, 4, 170-177.

WiTKOWICZ R., 2016. Wpływ zmian $w$ składzie mineralnym ziarna owsa nagoziarnistego na realizacje zalecanego lub wystarczajacego spożycia. Zesz. Probl. Post. Nauk Rol. 584, 127 138.

WitKowicz R., PISUlewsKa E., LESZCZYŃSKA T., PIATKOWSKA E., KIDACKA A., 2015. Podstawowy skład chemiczny oraz aktywność przeciwrodnikowa ziela wybranych genotypów owsa siewnego (Avena sativa). Zywność Nauka Technologia Jakość 4, 176-187.

WYNIKI (Wyniki produkcji roślinnej w 2015 r.), 2016. Główny Urzad Statystyczny, Warszawa.

Zhou M., Robards K., GlenNie-Holmes M., HelLIWELL S., 1999. Oat lipids. J. Am. Oil Chem. Soc. $76,159-169$.

Kosmos Vol. 67, 2, 409-414, 2018

\section{Krystyna Zarzecka ${ }^{1}$, Marek Gugata ${ }^{1}$, Iwona MystKowska ${ }^{2}$, Alicja Baranowska ${ }^{2}$, AnNa Si- KORSKA ${ }^{3}$, MAGDALENA ZARZECKA ${ }^{4}$}

${ }^{1}$ Department of Agrotechnology, Siedlce University of Natural Sciences and Humanities, 14 Prusa Str., 08-110 Siedlce, ${ }^{2}$ Department of Environment Sciences, Pope John Paul II State School of Higher Education, 95/97Sidorska Str., 21-500 Biała Podlaska, ${ }^{3}$ Department of Agriculture, The State Higher School of Vocational Education in Ciechanów, Narutowicza St. 9, 06-400 Ciechanów, ${ }^{4}$ Mazovia

Regional Hospital in Siedlce, 26 Poniatowskiego Str., 08-110 Siedlce,E-mail: kzarzecka@uph.edu.pl,gugala@uph.edu.pl

\section{NUTRITIONAL AND PRO-HEALTHY PROPERTIES OF OAT GRAIN AND OAT PRODUCTS}

\section{Summary}

The article presents a brief history of oat cultivation, botanical characteristic of the plant, chemical composition of its grain, nutritional and pro-health values and multi-purpose utilization. Oat and oat products are precious source of many bioactive nutrients components and substances such as: proteins, lipids, mineral compounds, vitamins, dietary fibre, beta-glucans, polyphenols. Oat is a health promoting grain for the human body. Nutritionists and physicians believe that oat products may be a beneficial diet supplement highly recommended for people suffering from such diseases as: gastrointestinal track disorders, atherosclerosis, hypertension, overweight and reduced psychophysical efficiency.

Key words: chemical composition, grain oat, health benefits, nutritional values 